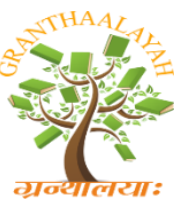

INTERNATIONAL JOURNAL OF RESEARCH GRANTHAALAYAH A knowledge Repository

Science

\title{
COST BENEFIT ANALYSIS OF INSTALLING OF SOLAR AND WIND POWER PLANT USING DIFFERENT PARAMETER
}

\author{
Amit Kumar Kishanpuri ${ }^{* 1}$, Dr. A.K.Sharma ${ }^{2}$ \\ ${ }^{* 1}$ Research Scholar, Fourth Semester ME (High Voltage \& Power System.), Jabalpur \\ Engineering College, Jabalpur (M.P) 482011, India \\ ${ }^{2}$ Professor \& HOD, Department of Electrical Engineering, Jabalpur Engineering College, \\ Jabalpur (M.P) 482011, India
}

DOI: https://doi.org/10.29121/granthaalayah.v5.i3.2017.1786

\begin{abstract}
In this paper, we are discussing about the solar power plant and wind power plant. The electrical power is depend on the ray of sun. These are optimizing output by following the sun across the sky for maximum sunlight. These typically give you about a 15\% increase in winter and up to a $35 \%$ increase in summer. The panel temperatures are much lower in winter, and then find out the minimum power. And the panel temperatures are higher in summer, and then find out the maximum power.
\end{abstract}

Keywords: Cost Analysis; Parameter; Tariff.

Cite This Article: Amit Kumar Kishanpuri, and Dr. A.K.Sharma. (2017). "COST BENEFIT ANALYSIS OF INSTALLING OF SOLAR AND WIND POWER PLANT USING DIFFERENT PARAMETER." International Journal of Research - Granthaalayah, 5(3), 310-314. https://doi.org/10.29121/granthaalayah.v5.i3.2017.1786.

\section{Introduction}

A solar charge controller is fundamentally a voltage or current controller to charge the battery and keep electric cells from overcharging. It directs the voltage and current hailing from the solar panels setting off to the electric cell. Generally, 12V boards/panels put out in the ballpark of 16 to $20 \mathrm{~V}$, so if there is no regulation the electric cells will damaged from overcharging. Generally, electric storage devices require around 14 to $14.5 \mathrm{~V}$ to get completely charged. The solar charge controllers are available in all features, costs and sizes. The range of charge controllers are from $4.5 \mathrm{~A}$ and up to 60 to $80 \mathrm{~A}$.

\section{Types of Solar Charger Controller}

There are three different types of solar charge controllers, they are: 
1) Simple 1 or 2 stage controls

2) PWM (pulse width modulated)

3) Maximum power point tracking (MPPT)

\section{Simple 1 or 2 Controls}

It has shunt transistors to control the voltage in one or two steps. This controller basically just shorts the solar panel when a certain voltage is arrived at. Their main genuine fuel for keeping such a notorious reputation is their unwavering quality - they have so not many segments, there is very little to break.

\section{PWM (Pulse Width Modulated)}

This is the traditional type charge controller, for instance anthrax, Blue Sky and so on. These are essentially the industry standard now. Simple solar charge controllers just disconnect or shunt the solar battery when battery's voltage reaches about $14.4 \mathrm{~V}$ (for storage battery with rated voltage $12 \mathrm{~V})$.

\section{Maximum power point tracking (MPPT)}

The MPPT solar charge controller is the sparkling star of today's solar systems. These controllers truly identify the best working voltage and amperage of the solar panel exhibit and match that with the electric cell bank. The outcome is extra 10-30\% more power out of your sun oriented cluster versus a PWM controller. It is usually worth the speculation for any solar electric systems over 200 watts.

\section{Solar Power Plant Calculation}

We have calculated what is the radiation received by the panels per sqm. But, depending on the panels chosen and size of the solar power plant, the area of the panels is going to be different.

Assuming, a $1 \mathrm{~kW}$ solar plant having 4 standard $250 \mathrm{Wp}$ panels of $1 \mathrm{~m} \times 1.65 \mathrm{~m}$, which leads to a cumulative area of $6.6 \mathrm{sqm}$. We, further, multiply the radiation calculated per sqm $(2,300$ $\mathrm{kWh} / \mathrm{sqm})$ with the total area $(6.6 \mathrm{sqm})$ to get the total radiation falling on the plant:

$2,300 \times 6.6=15180 \mathrm{kWh}$

\section{Current}

Every panel has got its own ability to covert the solar radiation that it receives into DC Current. The percentage of radiation that gets converted into DC Current, is known as efficiency of panels which can be in the range of $7 \%$ to $20 \%$ and even higher.

The most common polycrystalline panels available today have efficiency of $15.5 \%$ leading to a DC Current of: 
$15180 \mathrm{kWh} \times 15.5 \%=2352.9 \mathrm{kWh} /$ year

\section{Losses}

The DC Current generated undergoes a series of losses before it can finally become AC Current and used by us. A summary of these losses is given below:

As $15-25 \%$ of the DC Current is lost through above losses, leading to the final generation:

$2352.9 \mathrm{kWh} /$ year $\times 75 \%$ (subtracting losses) $=1765 \mathrm{kWh}$

\section{Total cost of solar power plant}

One solar plate cost 12V. D.C. , 250W = Rs 10350

Cost For $1 \mathrm{KW}=$ Total No. of solar plate $\mathrm{X}$ Rs of one solar plate

Cost For $1 \mathrm{KW}=4 \mathrm{X} 10350$

Cost of panels $=41400$

Cost of mounting structures $=2000$

Cost of inverter $=5000$

Total cost of a $1 \mathrm{~kW}$ solar power plant $=\mathrm{Rs} 48400$

\begin{tabular}{|l|l|l|l|}
\hline Sr. No. & Year & units & capacity \\
\hline $\mathbf{1}$ & $1-5$ & 8780 & $100 \%$ rated capacity \\
\hline $\mathbf{2}$ & $6-10$ & 7902 & $90 \%$ rated capacity \\
\hline
\end{tabular}

Total number of units generated over 10 years $=16682$

The cost per unit of electricity generated $=R s 48400 / 16682=R s 2.90$

\section{Wind Power plant Calculation}

The formula for calculating the power from a wind turbine is:

$$
\text { Power }=k \mathrm{C}_{\mathrm{p}} 1 / 2 \rho \mathrm{AV}^{3}
$$

Where:

$\mathrm{P}=$ Power output, kilowatts

$\mathrm{Cp}=$ Maximum power coefficient, ranging from 0.25 to 0.45 , dimension less (theoretical maximum $=0.59$ )

$\rho=$ Air density, $\mathrm{lb} / \mathrm{ft}^{3}$

$\mathrm{A}=$ Rotor swept area, $\mathrm{ft}^{2}$ or $\pi \mathrm{D} 2 / 4$ ( $\mathrm{D}$ is the rotor diameter in $\mathrm{ft}, \pi=3.1416$ )

$\mathrm{V}=$ Wind speed, mph

$\mathrm{k}=0.000133$ A constant to yield power in kilowatts. (Multiplying the above kilowatt answer by 1.340 converts it to horse- power [i.e., $1 \mathrm{~kW}=1.340$ horsepower]). 
The rotor swept area, A, is important because the rotor is the part of the turbine that captures the wind energy. So, the larger the rotor, the more energy it can capture.

The air density, $\rho$, changes slightly with air temperature and with elevation. The ratings for wind turbines are based on standard conditions of $59^{\circ} \mathrm{F}\left(15^{\circ} \mathrm{C}\right)$ at sea level. A density correction should be made for higher elevations as shown in the Air Density Change with Elevation graph. A correction for temperature is typically not needed for predicting the long-term performance of a wind turbine.

\section{Component cost}

4 blade cost $=4 X 4000=16000$

D.C. generator cost $=13000$

Shaft and gear box $=8000$

Bearing cost and housing $=1800$

Frame, support, clamp and base $=15000$

Total cost of a $1 \mathrm{~kW}$ wind power plant = Rs 58300

\begin{tabular}{|l|l|l|l|}
\hline Sr. No. & Year & units & capacity \\
\hline $\mathbf{1}$ & $1-5$ & 8000 & $100 \%$ rated capacity \\
\hline $\mathbf{2}$ & $6-10$ & 6400 & $80 \%$ rated capacity \\
\hline
\end{tabular}

Total number of units generated over 10 years $=14400$

\section{The cost per unit of electricity generated $=$ Rs $58300 / 14400=$ Rs 4.04}

\section{Conclusion}

The solar power plant and wind power plant are having the different tariff, which are depending on the various cost. In solar power plant, we are finding out the cost per unit of electricity generated are Rs 2.90. In Wind Power plant, we are finding out the cost per unit of electricity generated are Rs 4.04 .

\section{References}

[1] Deshmukha.M.K. and Deshmukhb.S.S (2008) Modelling of Hybrid Renewable Energy Systems, Renewable and Sustainable Energy Reviews, Vol.26, 235-249.

[2] HosainZaman, HamedShakouri G, (2011), A simple mathematical model for wind turbine power maximization with cost constraints, Iraq Journal of Electrical and Electronic Engineering, Vol-7, 60-63.

[3] India wind Energy Outlook (2012), Global wind Energy Council, 3rd Edition, An International Conference \& exhibition, Chennai.

[4] Jayabalan.P Research Associate, A study on power scenario in Tamilnadu, Center for Asia Studies, Chennai 1-55.

[5] Moolsingh, (2010) Conventional and Renewable energy scenario of India: present and Future Canadian Journal of Electrical and Electronics Engineering, Vol 1, 122-140. 
[6] Ch Sai Babu et.al, Mathematical Model of Photovoltaic System with Maximum Power Point Tracking (MPPT) International Conference on Advances in Engineering and Technology, (ICAET-2011), May 27-28, 2011.

[7] Nabil A, Rajamohan G, Kenneth A.S., Ling C. J.', "The Study And Evaluation Of Maximum Power Point Tracking Systems", Proceedings Of International Conference On Energy And Environment 2006 (ICEE 2006), Organized by University Tenaga Nasional, Bangi, Selangor, Malaysia; 28-30 August 2006, pp.17-22.

[8] Jawad Ahmad, "A Fractional Open Circuit Voltage Based Maximum Power Point Tracker for Photovoltaic Arrays", Proceedings of 2nd IEEE International Conference on Software Technology and Engineering, ICSTE 2010, pp. 287-250.

[9] M. Azab, "A New Maximum Power Point Tracking for Photovoltaic Systems, "in WASET.ORG, vol. 34,2008, pp. 571-574

[10] Vikrant. A. Chaudhari, "Automatic Peak Power Traker for Solar PV Modules Using dSpacer Software.," in Maulana Azad National Institute Of Technology vol. Degree of Master of Technology In Energy. Bhopal: Deemed University, 2005, pp. 98 